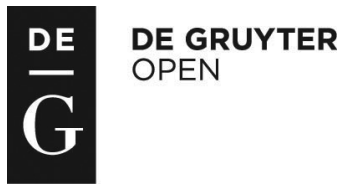

\title{
EFFECT OF SOUS-VIDE TECHNIQUE ON FATTY ACID AND MINERAL COMPOSITIONS OF BEEF AND LIVER FROM BONSMARA AND NON-DESCRIPT CATTLE*
}

\author{
Andrew Bamidele Falowo', Voster Muchenje ${ }^{1}$, Arno Hugo ${ }^{2}$ \\ ${ }^{1}$ Department of Livestock and Pasture Science, Faculty of Science and Agriculture, \\ University of Fort Hare, P. Bag X1314, Alice 5700, Eastern Cape Province \\ ${ }^{2}$ Department of Microbial Biochemical and Food Biotechnology, University of the Free State, \\ P.O. Box 339, Bloemfontein, 9300, South Africa \\ •Corresponding author: anddele2013@gmail.com
}

\begin{abstract}
This study examined the fatty acid and mineral compositions of raw and cooked beef and liver from Bonsmara (BD) and non-descript (ND) cattle, raised on natural pasture. Samples were collected from 80 cows and thermal-processed at $65^{\circ} \mathrm{C}$ for 120 minutes and $85^{\circ} \mathrm{C}$ for 60 minutes using sous-vide techniques, and then analysed for fatty acid and mineral compositions. The results did not show differences in individual fatty acid composition of meat samples between the breed $(\mathrm{P}>\mathbf{0 . 0 5})$. However, the raw beef sample had higher content of monounsaturated fatty acids (MUFA, 40.22\% $\pm \mathbf{3 . 7 9} \mathrm{ND}, \mathbf{4 2 . 5 3 \%} \pm \mathbf{2 . 3 9} \mathrm{BD}$ ) and lower content of polyunsaturated fatty acids (PUFA, 11.02\% $\pm 5.47 \mathrm{ND}, 10.13 \% \pm 6.73 \mathrm{BD}$ ) than liver (MUFA, 20.11\% $\pm 4.76 \mathrm{ND}, 21.08 \% \pm 2.46$ BD; PUFA, 30.73\% \pm 5.20 ND, $31.11 \% \pm 2.37$ BD) $(P<0.05)$. The PUFA/MUFA and $n-6 / n-3$ ratios, atherogenicity and desaturase indices were comparable between breeds, but higher in beef than liver. The total percentage of saturated fatty acid, MUFA and PUFA retained after cooking were numerically higher in liver than in beef $(\mathrm{P}>0.05)$. The results further revealed higher contents of $\mathrm{Na}, \mathrm{Mg}$, and $\mathrm{Zn}$ in raw beef than liver. However, the content of $\mathrm{Na}, \mathrm{Mg}$, and $\mathrm{Zn}$ in the beef and liver were not significantly $(\mathrm{P}>\mathbf{0 . 0 5})$ affected after cooking. Based on the PUFA proportion of the total lipids in beef (11.02\%) and liver (31.11\%) and $n-6 / n-3$ PUFA ratio in beef (2.54) and liver (1.34), consumption of liver and beef from cattle raised on pasture could be beneficial to human health. Additionally, application of sous-vide technique can be used to minimize the nutritional losses in beef and liver.
\end{abstract}

Key words: cattle, fatty acids, minerals, thermal treatment

*This work was funded by Govan Mbeki Research and Development Centre (GMRDC) of the University of Fort Hare (UFH) and DAFF / NRF - RTF (Research and Technology Fund), Post slaughter meat handling (Project ID 92101). 
Beef among other meat products plays an important role in maintaining a healthy and balanced diet, because it provides energy, high-quality and readily digestible protein with all essential amino acids, and other absorbable micronutrients which are needed for human growth, cell functioning and sound health (De Smet, 2012; Czerwonka et al., 2014; Mourouti et al., 2015). Liver also provides a wide range of important macro and micro nutrients which are comparable with lean muscle tissue. According to Li et al. (2014), beef liver contains 17-19\% protein, 3-5\% fat, $1.5 \%$ ash, 2-4\% carbohydrate and 103-140 kcal total energy. In addition, liver contains higher amounts of amino acids (leucine, threonine, serine, glutamic acid, aspartic acid and phenylalanine), minerals (iron) and polyunsaturated fatty acids than fresh lean beef tissue (Enser et al., 1998; Jayathilakan et al., 2012; Li et al., 2014). Based on these nutritional qualities, the utilization of liver and other edible offal is essential in order to support viable meat production systems and also enhance food security across the world (Florek et al., 2012; Kurt and Zorba, 2007).

However, the bioavailability of essential nutrients for consumption may depend on the type of thermal treatment employed to transform raw meat to edible, palatable and ready-to-eat products (Severi et al., 1997). The use of different cooking methods, such as frying, microwaving and grilling, has been reported to induce free radical production, loss of essential fatty acids and other nutritive values including vitamins and minerals (Alfaia et al., 2010; Lopes et al., 2015). In addition, Alfaia et al. (2010) and Zhang et al. (2014) found that use of these thermal methods caused modification of polyunsaturated fatty acid (PUFA) and a severe reduction in essential amino acids, vitamins and mineral contents of cooked meat. The loss of macro and micro minerals during thermal processing can cause changes in muscle structure, decreasing the water holding capacity, sensory and nutritional quality of meat (Gerber et al., 2009; Czerwonka et al., 2015; Lopes et al., 2015). In order to minimize the nutrient loss while optimizing palatability and shelf life of meat during thermal treatment, many food processors now use sous-vide cooking technique to replace the conventional methods (frying, microwaving and grilling) (Sanchez del Pulgar et al., 2012; Roldan et al., 2014). Sous-vide technique refers to process of cooking meat in vacuum-sealed pouches inside temperature-controlled water environment for long periods of time (Roldan et al., 2014). This method allows greater control over degree of doneness compared to other cooking methods (Baldwin, 2012).

However, the effect of sous-vide cooking method on the nutritional composition of beef and liver from Bonsmara and non-descript cattle in terms of the fatty acid and mineral composition has not been fully studied. Bonsmara is one of the strongest and readily available South African cattle breeds which was developed from the crosses between local Afrikaner cows and European Shorthorn and Hereford bulls (Bonsmara SA, 2016). The non-descript cattle were developed from the indiscriminate crossing of the different indigenous breeds such as Nguni with exotic (Bos taurus) breeds. It is well known that the fatty acid and mineral profiles of meat products can vary according to muscle type, breed, age, diet, species and production region of the animal (Lopes et al., 2015). Therefore, the aim of this study was to evaluate the effect of sous-vide cooking method on fatty acid and mineral compositions of beef and liver from Bonsmara and non-descript cattle. 


\section{Material and methods}

\section{Sample collection and preparation}

Fresh beef steak samples were collected from musculus longissimus dorsi (thoracis et lumborum) of slaughtered Bonsmara and non-descript breed cow (beef cattle), which were reared on a natural pasture in Eastern Cape Province of South Africa. All animals were restrained in the stunning box and stunned using a captive bolt or penetrating gun stunner. The carcasses were electrically stimulated according to the abattoir guidelines at $300 \mathrm{~V}, 50 \mathrm{~Hz}$ and $5 \mathrm{~A}$ for $40-45 \mathrm{~s}$ at $12 \mathrm{pulse} / \mathrm{s}$. The age and final live weight of cattle before slaughter ranged from 4 to 5 years and 450 to $500 \mathrm{~kg}$, respectively. Fresh liver samples were also collected from the same cattle after slaughtered. The samples (about $150 \mathrm{~g}$ from each animal) were stored in a cooler box for approximately 180 min during transportation from abattoir to laboratory. After transportation, they were frozen at $-23^{\circ} \mathrm{C}$ refrigerator temperature until analysis. All beef (Bonsmara, $n=40$ samples; non-descripts, $n=40$ samples) and liver (Bonsmara, $\mathrm{n}=40$ samples; non-descripts, $\mathrm{n}=40$ samples) samples were divided into three groups: raw samples, samples cooked at $65^{\circ} \mathrm{C}$ (medium well) for 120 minutes and samples cooked at $85^{\circ} \mathrm{C}$ (well done) for 60 minutes, using sousvide method (Vaudagna et al., 2002; Garcia-Segovia et al., 2007; Alfaia et al., 2010). Prior to cooking, about 40-70 g of meat samples was weighed into a vacuum plastic bag and sealed using vacuum sealer (Genesis, 80-GVS, South Africa). Thereafter, the samples were submerged in thermostatized water bath that has been preheated to $65^{\circ} \mathrm{C}$ and $85^{\circ} \mathrm{C}$ and maintained within the water bath for 120 and 60 minutes, respectively. After cooking, samples were removed from the water bath, submerged in cold water for 10 minutes $\left(4^{\circ} \mathrm{C}\right)$ and cooled at room temperature. Samples for fatty acid and mineral determination were vacuum packaged immediately after cooling and stored at $-23^{\circ} \mathrm{C}$ until analysis.

\section{Determination of fatty acid profile of raw and cooked beef and liver}

Total lipid of the fresh and cooked beef and liver samples from each breed was quantitatively extracted as described by Folch et al. (1957), using chloroform and methanol in a ratio of 2:1. An antioxidant (butylated hydroxytoluene, BHT) was added at a concentration of $0.001 \%$ to the chloroform: methanol mixture. The fat extracts were dried in a rotary evaporator under vacuum and the extracts were dried overnight in a vacuum oven at $50^{\circ} \mathrm{C}$, using phosphorus pentoxide as moisture absorbent. Total extractable fat was determined gravimetrically from the extracted fat and expressed as percent fat (w/w) per $100 \mathrm{~g}$ tissue. Thereafter, the extracted fat muscle was stored in a polytop (glass vial, with push-in top) under a blanket of nitrogen and frozen at $-20^{\circ} \mathrm{C}$ for analysis of fatty acids. An aliquot $(30 \mathrm{mg}$ ) of muscle lipid was converted to methyl esters by base-catalysed transesterification, in order to avoid CLA isomerisation, with sodium methoxide ( $0.5 \mathrm{M}$ solution in anhydrous methanol) during $2 \mathrm{~h}$ at $30^{\circ} \mathrm{C}$, as described by Alfaia et al. (2007). Fatty acid methyl esters (FAMEs) from muscle were quantified using a Varian 430 flame ionization GC, with a fused silica capillary column, Chrompack CPSIL 88 (100 m length, $0.25 \mathrm{~mm}$ ID, $0.2 \mu \mathrm{m}$ film thicknesses). The analysis was performed using an initial isothermic 
period $\left(40^{\circ} \mathrm{C}\right.$ for 2 minutes) and gradually increased at a rate of $4^{\circ} \mathrm{C} /$ minute until a final temperature of $230^{\circ} \mathrm{C}$ was reached. Finally the isothermic period of $230^{\circ} \mathrm{C}$ was maintained for 10 minutes. FAMEs n-hexane $(1 \mu \mathrm{l})$ was injected into the column using a Varian CP 8400 Autosampler. The injection port and detector were both maintained at $250^{\circ} \mathrm{C}$. Hydrogen, at $45 \mathrm{psi}$, was used as the carrier gas, while nitrogen was employed as the makeup gas. Galaxy Chromatography Data System Software recorded the chromatograms. Fatty acid methyl ester samples were identified by comparing the retention times of FAME peaks from samples with those of standards obtained from Supelco (Supelco 37 Component Fame Mix 47885-U, Sigma-Aldrich Aston Manor, Pretoria, South Africa). Conjugated linoleic acid (CLA) standards were obtained from Matreya Inc. (Pleasant Gap, Unites States). These standards included: cis-9, trans-11 and trans-10, cis-12-18:2 isomers. Nonadecanoic acid (C19:0) (SIGMA N553377 - 1G) was used as the internal standard to improve quantitative FAME estimation. Fatty acids were expressed as the proportion of each individual fatty acid to the total of all fatty acids present in the sample. Fatty acid data were used to calculate the total SFAs total MUFAs; PUFAs; omega-6 and omega-3 PUFA; and following ratios: PUFA/SFA; PUFA/SFA; omega- 6 to omega-3 $(n-6) /(n-3)$ and $\Delta^{9}$ desaturase index $(\mathrm{C} 18: 1 c 9 / \mathrm{C} 18: 0)$; atherogenicity index (AI) was calculated as $(\mathrm{C} 12: 0+4 \times \mathrm{x} 14: 0+\mathrm{C} 16: 0) /(\mathrm{MUFA}+\mathrm{PUFA})$ (Chilliard et al., 2003). The percentage of fatty acids gain or loss in beef and liver after cooking at $65^{\circ} \mathrm{C}$ and $85^{\circ} \mathrm{C}$ was calculated as [(Fatty acid value of raw meat - fatty acid value of cooked meat) $\div$ fatty acid value of raw meat $] \times 100$. The fatty acid analysis was carried out in four replicates per breed, meat type and cooking temperature.

\section{Determination of mineral constituents of raw and cooked beef and liver}

The elemental constituents of potassium $(\mathrm{K})$, sodium $(\mathrm{Na})$, magnesium $(\mathrm{Mg})$, calcium $(\mathrm{Ca})$ and Zinc $(\mathrm{Zn})$ in beef $(\mathrm{n}=4)$ and liver $(\mathrm{n}=4)$ samples were determined after dry mineralisation, as described by Gorsuch (1970) and Tomović et al. (2011). Five gram of meat sample was weighed into a porcelain crucible and dried in a laboratory oven at $105^{\circ} \mathrm{C}$ for $3 \mathrm{~h}$. After drying, the samples were incinerated in a muffle furnace at $550^{\circ} \mathrm{C}$ overnight until the white ash formed. The ash was solubilized with $20 \mathrm{ml}$ of $\mathrm{HNO}_{3}(0.5 \mathrm{~N})$ in an Erlenmeyer flask and heated to reduce the volume to $5 \mathrm{ml}$. The solution was then filtered through ash-free filter paper into a $50-\mathrm{mL}$ volumetric flask. Each sample solution was made up with dilute $\mathrm{HNO}_{3}(0.5 \mathrm{~N})$ to a final volume of $50 \mathrm{~mL}$ and analysed by flame atomic absorption spectrometry (FAAS; air-acetylene flame) using a Thermo Fisher iCE3500 spectrometer (China). During the analysis, deuterium background correction was used and limits of quantification (LOQ) and detection (LOD) were taken into account. The mineral analysis was carried out in four replicates per breed, meat type and cooking temperature

\section{Statistical analysis}

The Statistical Analysis System (SAS version 9.1.3 of 2007) was used for all the analyses. PROC GLM procedure of SAS was used to consider the effect of breed (Bonsmara and non-descripts) and meat type (beef and liver) on the fatty acid and mineral content of raw meat samples. While the effect of sous-vide cooking tem- 
perature $\left(65^{\circ} \mathrm{C}\right.$ and $\left.85^{\circ} \mathrm{C}\right)$, meat type (beef and liver) and their interactions was performed on the fatty acid profiles, mineral content of meat samples. The statistical model included breed, sous-vide cooking temperature, meat type (beef and liver), breed $\times$ meat type (beef and liver), meat type (beef and liver) $\times$ sous-vide cooking temperature as main effects. Significant differences between the least square means for beef and liver were performed using the Fishers' least significance difference (LSD) method of SAS, with significance level of $\mathrm{P}<0.05$.

\section{Results}

\section{Proximate composition of raw and cooked beef and liver}

Results on proximate analysis of selected nutrients in raw beef and liver from cattle are presented in Table 1. The results revealed no statistical differences in intramuscular fat, fat free dry matter and moisture contents in liver and beef between the breeds $(\mathrm{P}>0.05)$. However, liver from Bonsmara and non-descript cattle had a higher percentage of intramuscular fat content of $4.67 \%$ and $4.44 \%$ respectively, and fat free dry matter of $27.51 \%$ and $25.73 \%$, respectively, than the beef $(\mathrm{P}<0.05)$. More so, the moisture content of the liver was much lower than that of beef samples. Similar trend was also observed in the cooked samples with liver having higher intramuscular fat than beef samples (Table 2). Application of thermal treatment on beef and liver at $85^{\circ} \mathrm{C}$ revealed a higher fat free dry matter and lower moisture content than those cooked at $65^{\circ} \mathrm{C}$. However, the value of intramuscular fat in beef was similar at $85^{\circ} \mathrm{C}$ (3.64) and $65^{\circ} \mathrm{C}(3.64)$ cooking temperature.

Table 1. Proximate composition of selected nutrients in raw beef and liver

\begin{tabular}{|c|c|c|c|c|c|c|c|c|}
\hline & \multicolumn{4}{|c|}{ Meat type (M) } & \multirow{4}{*}{ SEM } & \multirow{3}{*}{\multicolumn{3}{|c|}{ P-value }} \\
\hline & \multicolumn{2}{|c|}{ beef } & \multicolumn{2}{|c|}{ liver } & & & & \\
\hline & \multicolumn{4}{|c|}{ Breed (B) } & & & & \\
\hline & ND & $\mathrm{BD}$ & ND & $\mathrm{BD}$ & & B & $\mathrm{M}$ & $\mathrm{B} \times \mathrm{M}$ \\
\hline Intramuscular fat (\%) & 2.04 & 2.40 & 4.44 & 4.67 & 0.38 & 0.45 & $<0.001$ & 0.86 \\
\hline Fat free dry matter $(\%)$ & 22.82 & 22.14 & 25.73 & 27.51 & 0.81 & 0.51 & 0.003 & 0.15 \\
\hline Moisture (\%) & 75.14 & 75.45 & 69.83 & 67.82 & 0.99 & 0.41 & $<0.001$ & 0.27 \\
\hline
\end{tabular}

$\mathrm{n}=8[$ Non-descript $(\mathrm{ND})=4$, Bonsmara $(\mathrm{BD})=4]$. Significance: $(\mathrm{P} \leq 0.05)$. Not significant: $(\mathrm{P}>0.05)$.

Table 2. Proximate composition of selected nutrients in raw and cooked beef and liver

\begin{tabular}{|c|c|c|c|c|c|c|c|c|c|c|}
\hline & \multicolumn{6}{|c|}{ Meat type (M) } & \multirow{4}{*}{ SEM } & \multirow{3}{*}{\multicolumn{3}{|c|}{ P-value }} \\
\hline & \multicolumn{3}{|c|}{ beef } & \multicolumn{3}{|c|}{ liver } & & & & \\
\hline & \multicolumn{6}{|c|}{ Temperature $(\mathrm{T})$} & & & & \\
\hline & Raw & $65^{\circ} \mathrm{C}$ & $85^{\circ} \mathrm{C}$ & Raw & $65^{\circ} \mathrm{C}$ & $85^{\circ} \mathrm{C}$ & & $\mathrm{T}$ & M & $\mathrm{T} \times \mathrm{M}$ \\
\hline Intramuscular fat (\%) & 3.24 & 3.64 & 3.64 & 3.54 & 5.13 & 6.77 & 0.41 & 0.001 & $<0.001$ & 0.01 \\
\hline Fat free dry matter $(\%)$ & 24.27 & 28.54 & 36.68 & 24.82 & 26.36 & 31.15 & 0.83 & $<0.001$ & 0.004 & 0.01 \\
\hline Moisture (\%) & 72.48 & 67.82 & 59.68 & 71.64 & 68.51 & 61.38 & 1.03 & $<0.001$ & 0.59 & 0.50 \\
\hline
\end{tabular}

$\mathrm{n}=8[$ Non-descript $(\mathrm{ND})=4$, Bonsmara $(\mathrm{BD})=4]$. Significance: $(\mathrm{P} \leq 0.05)$. Not significant: $(\mathrm{P}>0.05)$. 


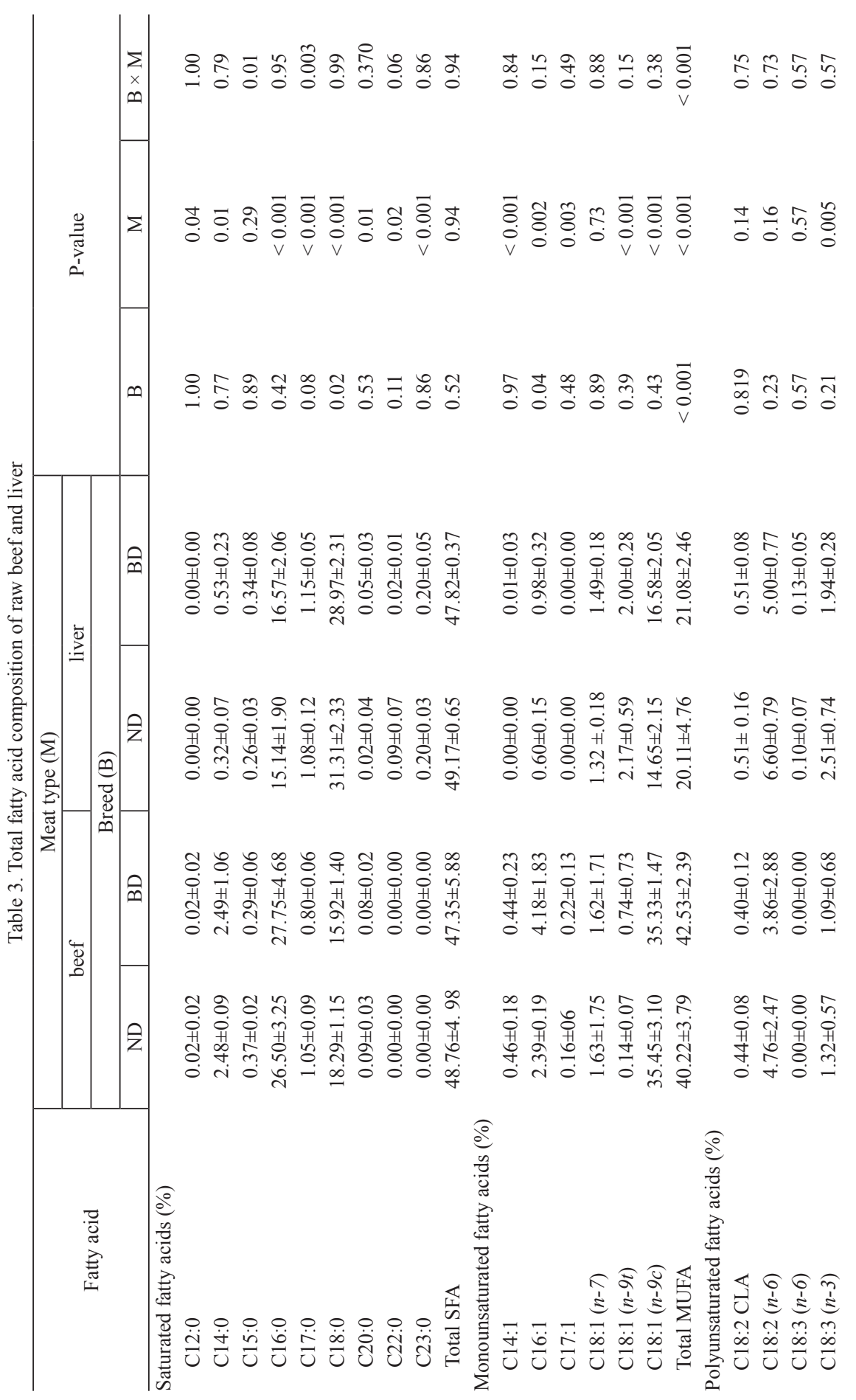




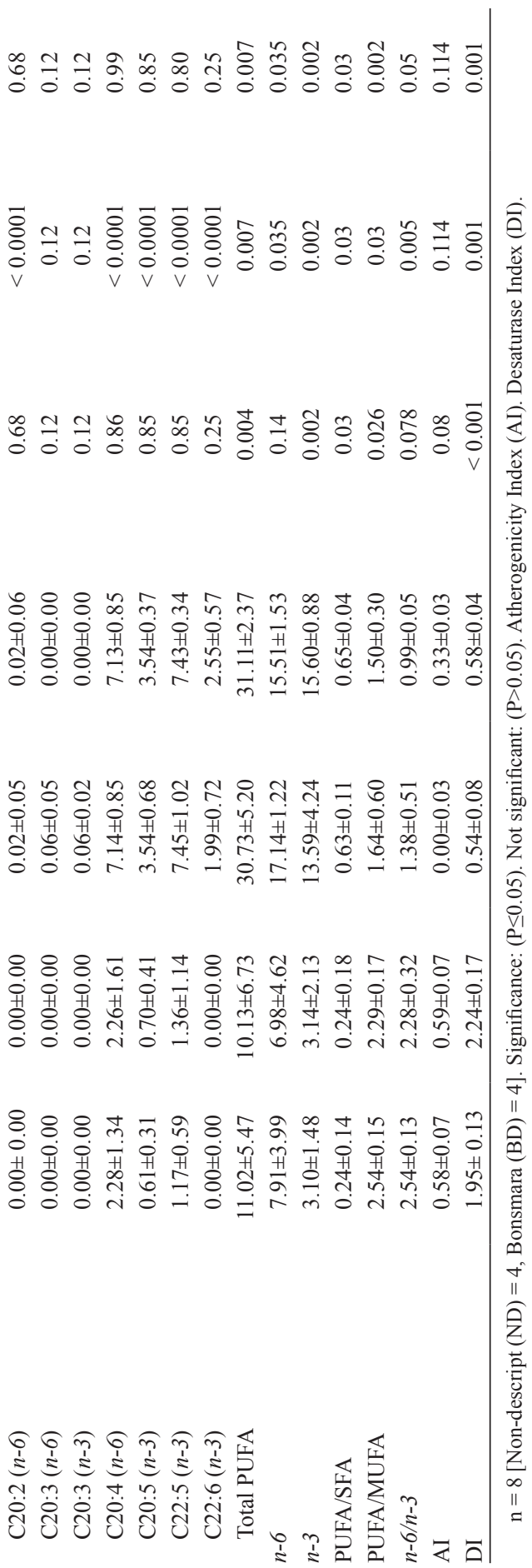




\section{Fatty acid composition of raw beef and liver}

Table 3 showed the result of the fatty acid composition of raw beef and liver. There was no significant difference in individual fatty acid composition of raw beef and liver between the breeds $(\mathrm{P}>0.05)$. However, among individual saturated fatty acids (SFA), beef revealed significantly $(\mathrm{P}<0.05)$ higher content of $\mathrm{C} 12: 0, \mathrm{C} 16: 0$ and $\mathrm{C} 20: 0$ and lower content of $\mathrm{C} 14: 0$ and $\mathrm{C} 18: 0$ than liver $(\mathrm{P}<0.05)$. Similarly, the individual composition of monounsaturated fatty acids (MUFA) showed that beef had higher content of C14:1, C16:1, C17:1, C18:1 $(n-9 c)$ and total MUFA than liver (Table 3). While the polyunsaturated fatty acid (PUFA) profile of liver revealed higher content of C18:3 (n-3), C20:4 (n-6), C20:5 (n-3), C22:5 (n-3) and C22:6 ( $n-3)$ than beef $(\mathrm{P}<0.05)$. In general, the total MUFA $(\mathrm{P}<0.05)$ values were relatively lower in liver $(20.11 \pm 4.76 \% \mathrm{ND}, 21.08 \pm 2.46 \% \mathrm{BD})$ than in beef $(40.22 \pm 3.79 \% \mathrm{ND} ; 42.53 \pm 1.20 \% \mathrm{BD})$, whereas PUFA values $(\mathrm{P}<0.05)$ were higher in liver $(30.73 \pm 5.20 \% \mathrm{ND}, 31.11 \pm 2.37 \% \mathrm{BD})$ than in beef $(11.02 \pm 5.47 \% \mathrm{ND}$, $10.13 \pm 6.73 \% \mathrm{BD})$. The content of SFA in beef did not differ significantly from the liver $(\mathrm{P}>0.05)$. Furthermore, it was observed that the values of total $n-6, n-3$ and PUFA: SFA were higher in liver than in muscle tissue $(\mathrm{P}<0.05)$. While PUFA/MUFA and $n-6 / n-3$ ratios, atherogenicity (AI) and desaturase indexes (DI) were lower in liver than beef.

\section{Effect of sous-vide thermal temperature on fatty acid composition of beef and liver}

As shown in Table 4, the total fatty acid composition in beef and liver were not significantly $(\mathrm{P}>0.05)$ affected by application of sous-vide cooking method at $65^{\circ} \mathrm{C}$ and $85^{\circ} \mathrm{C}$. However, the contents of PUFA, $n-6$, PUFA/SFA, PUFA/MUFA, were numerically higher at $85^{\circ} \mathrm{C}$ than at $65^{\circ} \mathrm{C}$ cooking temperature for both beef and liver. The percentage of PUFA, $n-6, n-3$, PUFA/SFA, PUFA/MUFA, $n-6 / n-3$, atherogenicity index and desaturase index loss in relation to raw samples after cooking at $65^{\circ} \mathrm{C}$ and $85^{\circ} \mathrm{C}$ was numerically higher in beef than liver (Table 5).

\section{Mineral composition of raw beef and liver}

The results of mineral contents in raw beef and liver are presented in Table 6. The major minerals present were potassium (beef $213.7-221.7 \mathrm{mg} / 100 \mathrm{~g}$, liver $171.1-271.8 \mathrm{mg} / 100 \mathrm{~g}$ ), followed by magnesium (beef $52-53.7 \mathrm{mg} / 100 \mathrm{~g}$, liver 41-56.1 mg/100 g), sodium (29.3-48.4 mg/100 g, liver 32.9-43.9 mg/100 g), zinc (8.9-19.5 mg/100 g, liver 8.5-17.3 mg/100 g) and calcium (12.9-13.9 mg/100 g, liver $17.0-17.5 \mathrm{mg} / 100 \mathrm{~g})$. The concentration of $\mathrm{Ca}$ and $\mathrm{Zn}$ in beef and liver was significantly different between breeds $(\mathrm{P}<0.05)$. The concentration of $\mathrm{Ca}$ in liver from Bonsmara $(17.50 \mathrm{mg} / 100 \mathrm{~g})$ and non-descript $(17.00 \mathrm{mg} / 100 \mathrm{~g})$ was higher than that of beef while the concentration of $\mathrm{Zn}$ in beef from non-descript $(19.60 \mathrm{mg} / 100 \mathrm{~g})$ and Bonsmara $(8.90 \mathrm{mg} / 100 \mathrm{~g})$ was higher than that of liver (ND $17.30 \mathrm{mg} / 100 \mathrm{~g}, \mathrm{BD} 8.50 \mathrm{mg} / 100 \mathrm{~g}$ ). However, there was no significant interaction observed $(\mathrm{P}>0.05)$ in mineral content between liver and beef except for sodium $(\mathrm{Na})$. 


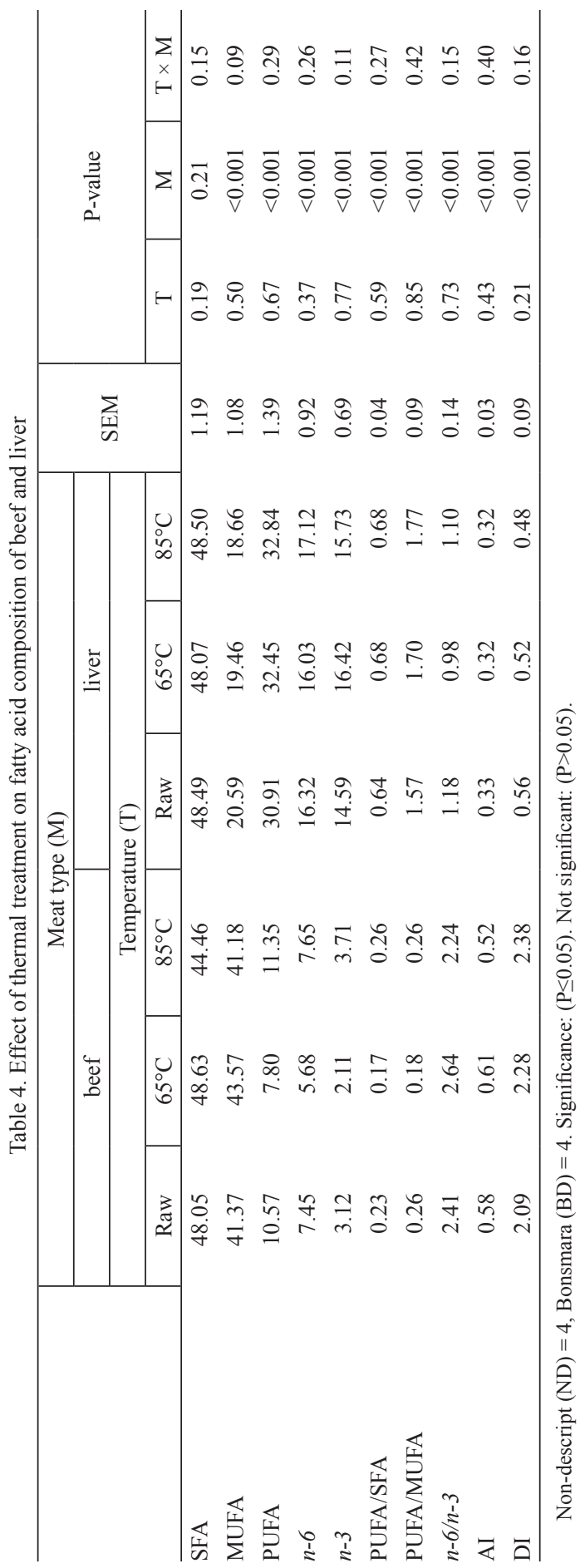




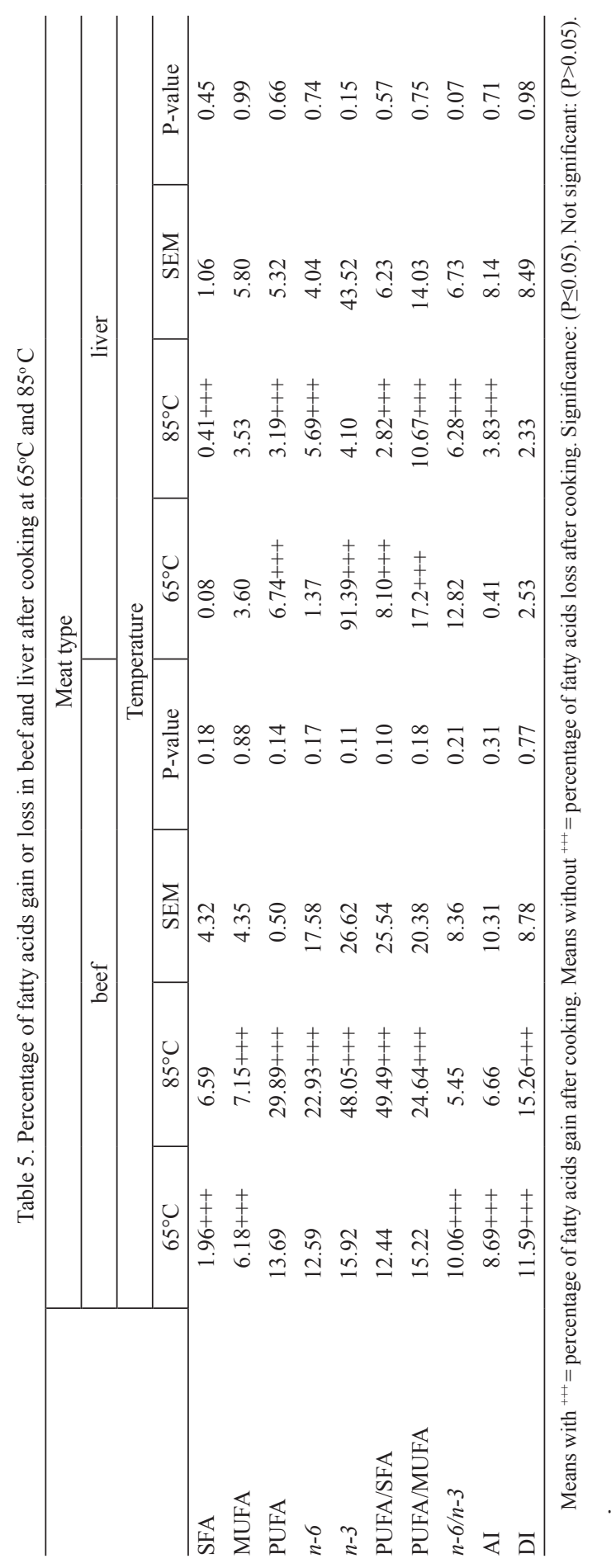


Table 6. Mineral composition (mg/100 g) of raw beef and liver

\begin{tabular}{|c|c|c|c|c|c|c|c|c|}
\hline & \multicolumn{4}{|c|}{ Meat type (M) } & \multirow{4}{*}{ SEM } & \multirow{3}{*}{\multicolumn{3}{|c|}{ P-value }} \\
\hline & \multicolumn{2}{|c|}{ beef } & \multicolumn{2}{|c|}{ liver } & & & & \\
\hline & \multicolumn{4}{|c|}{ Breed (B) } & & & & \\
\hline & ND & $\mathrm{BD}$ & ND & $\mathrm{BD}$ & & $\mathrm{B}$ & $\mathrm{M}$ & $\mathrm{B} \times \mathrm{M}$ \\
\hline$\overline{\mathrm{Ca}}$ & 12.90 & 13.90 & 17.00 & 17.50 & 0.90 & 0.01 & 0.57 & 0.85 \\
\hline $\mathrm{Na}$ & 29.30 & 48.40 & 43.90 & 32.90 & 4.20 & 0.94 & 0.51 & 0.02 \\
\hline $\mathrm{Mg}$ & 53.70 & 52.80 & 56.10 & 41.80 & 3.90 & 0.19 & 0.45 & 0.24 \\
\hline $\mathrm{K}$ & 213.7 & 221.7 & 271.1 & 171.8 & 18.50 & 0.88 & 0.11 & 0.06 \\
\hline $\mathrm{Zn}$ & 19.60 & 8.90 & 17.30 & 8.50 & 1.50 & 0.001 & 0.55 & 0.67 \\
\hline
\end{tabular}

Non-descript $(N D)=4$; Bonsmara $(B D)=4$. Significance: $(P \leq 0.05)$. Not significant: $(P>0.05)$.

\section{Effect of thermal treatment on mineral composition of beef and liver}

As shown in Table 7, application of sous-vide cooking method at $65^{\circ} \mathrm{C}$ and $85^{\circ} \mathrm{C}$ had no significant $(\mathrm{P}>0.05)$ effect on the concentration of minerals in beef and liver samples. However, on the one hand, the mean concentrations of $\mathrm{K}$ and $\mathrm{Mg}$ were numerically lower in beef and higher in liver after cooking at $85^{\circ} \mathrm{C}$ compared to raw samples. Conversely at $65^{\circ} \mathrm{C}$ cooking temperature, the values of $\mathrm{Zn}, \mathrm{Ca}, \mathrm{Mg}$ and $\mathrm{K}$ in beef were not numerically different compared to the raw sample. While on the other hand, the values of $\mathrm{Ca}, \mathrm{Mg}$ and $\mathrm{K}$ were lower in liver after cooking at $65^{\circ} \mathrm{C}$.

Table 7. Effect of sous-vide technique on mineral compositions (mg/100 g) of raw and cooked beef and liver

\begin{tabular}{|c|c|c|c|c|c|c|c|c|c|c|}
\hline & \multicolumn{6}{|c|}{ Meat type (M) } & \multirow{4}{*}{ SEM } & \multirow{3}{*}{\multicolumn{3}{|c|}{$\mathrm{P}$-value }} \\
\hline & \multicolumn{3}{|c|}{ beef } & \multicolumn{3}{|c|}{ liver } & & & & \\
\hline & \multicolumn{6}{|c|}{ Temperature $(\mathrm{T})$} & & & & \\
\hline & Raw & $65^{\circ} \mathrm{C}$ & $85^{\circ} \mathrm{C}$ & Raw & $65^{\circ} \mathrm{C}$ & $85^{\circ} \mathrm{C}$ & & $\mathrm{T}$ & M & $\mathrm{B} \times \mathrm{M}$ \\
\hline $\mathrm{Ca}$ & 13.45 & 13.45 & 13.98 & 17.28 & 13.60 & 15.77 & 0.70 & 0.05 & 0.03 & 0.05 \\
\hline $\mathrm{Na}$ & 38.80 & 38.88 & 38.87 & 38.37 & 49.85 & 49.80 & 4.50 & 0.49 & 0.58 & 0.91 \\
\hline $\mathrm{Mg}$ & 53.26 & 53.26 & 46.82 & 48.96 & 49.85 & 49.80 & 3.20 & 0.58 & 0.57 & 0.49 \\
\hline $\mathrm{K}$ & 217.51 & 217.51 & 202.27 & 221.48 & 175.86 & 248.27 & 16.60 & 0.20 & 0.84 & 0.04 \\
\hline $\mathrm{Zn}$ & 14.21 & 14.21 & 20.29 & 12.86 & 18.57 & 12.78 & 3.20 & 0.56 & 0.56 & 0.18 \\
\hline
\end{tabular}

Non-descript $(\mathrm{ND})=4$; Bonsmara $(\mathrm{BD})=4$. Significance: $(\mathrm{P} \leq 0.05)$. Not significant: $(\mathrm{P}>0.05)$.

\section{Discussion}

The content of intramuscular fat and fat free dry matter in liver was relatively higher than that of the beef. Application of sous-vide cooking technique at $65^{\circ} \mathrm{C}$ and 
$85^{\circ} \mathrm{C}$ led to significant loss of moisture and, consequently, a higher intramuscular fat and fat free dry matter content in both liver and beef compared to the raw samples. This is similar to the findings of Alfaia et al. (2010) who reported a significant reduction in moisture content and higher increase in intramuscular fat of cooked beef compared to raw beef. Other authors have also reported an increase in nutrient composition of meat (including fat content) as moisture content decreases during cooking (Badiani et al., 2004; Alfaia et al., 2010). Variation in fatty acid composition of raw and cooked beef and liver samples as observed in this study is in line with previous results reported by Alfaia et al. (2010) for fatty acid profile of liver and beef of cattle raised and finished on pasture (Alfaia et al., 2010). The higher proportion of PUFA, $n-6$ and $n-3$ observed in the values of raw liver than beef could be linked to the ability of liver to synthesize most of $n-6$ and $n-3$ long-chain polyunsaturated fatty acids from dietary precursors during lipid metabolism in the body (Araya et al., 2010; Valenzuela et al., 2012). This could also adduce for higher total fat and fat free dry matter found in liver in this study. However, omega-6 PUFA (arachidonic acid) and omega-3 PUFA (eicosapentaenoic and docosahexaenoic acids) have been identified in several physiological functions including regulation of inflammation and prevention of transmissible chronic diseases (Nantapo et al., 2015). This result is in line with other studies that have shown that liver contained higher level of polyunsaturated fatty acid than lean muscle tissue (Enser et al., 1998; Jayathilakan et al., 2012).

The non-significant difference between raw beef and liver from Bonsmara and non-descripts cattle indicated that their genotypes did not have effect on fatty acid contents since both animals were reared on natural pasture. Similar result has been reported by Xie et al. (2012) who found no significant influence of breed of cattle fed the same diet on fatty acid composition. However, our results are in contrast with the finding of Li et al. (2014) and Orellana et al. (2009) who had reported significant breed effect on fatty acid composition of liver and beef, respectively.

Furthermore, the total SFA and MUFA contents observed in raw beef and liver were relatively higher than those reported by Li et al. (2014) and Alfaia et al. (2010), respectively. However, the content of PUFA in raw liver was higher than that reported by Li et al. (2014) while that of raw beef was lower than that reported by Alfaia et al. (2010), but comparable with the report of Sarriés et al. (2009) and Legako et al. (2015). The ratio of PUFA/SFA, PUFA/MUFA, $n-6 / n-3$, as well as AI and DI recorded in raw beef and liver in this study were in contrast with those found by other authors (Sarriés et al., 2009; Alfaia et al., 2010; Li et al., 2014). These contrasting differences may be attributed to factors such as slaughter age, diet, meat cut and seasonal variation which have been reported to influence fatty acid composition of ruminants (Orellana et al., 2009).

The amount of fatty acid loss after cooking in this study was relatively lower compared to other studies that used cooking methods such as boiling, grilling and microwaving (Alfaia et al., 2010). Several mechanisms, such as water loss and lipid oxidation, diffusion and exchange that occur during cooking have been suggested to lead to relative changes in FA compositions (Alfaia et al., 2010). This indicates that sous-vide cooking method was able to minimize nutrient loss and prevent oxidation of fatty acid content by reducing the contact of free oxygen with meat sample $(\mathrm{Oz}$ 
and Zikirov, 2015). Consequently, sous-vide thermal treatment had lower cooking effect on liver sample than beef. This indicates that beef is more susceptible to nutrient loss and lipid oxidation than liver during cooking.

Considering the mineral composition of liver and beef in this study, the concentration of $\mathrm{K}$ and $\mathrm{Na}$ in raw beef and liver was slightly lower than the values reported by Czerwonka and Szterk (2015) and Lopes et al. (2015), but higher than that of Reykdal et al. (2014). Equally, the level of Mg observed in raw beef and liver in this study was higher than the values reported by Czerwonka and Szterk (2015) and Duan et al. (2015). The content of $\mathrm{Ca}$ and $\mathrm{Zn}$ in beef and liver was in contrast with values reported by Reykdal et al. (2014). However, these contrasting differences in the values reported in this study compared to other literature could be attributed to factors such as the type of cuts, age of the animals, sex, diet, genetic factors, physiological state, geographical site of rearing and method of mineral content determination (Czerwonka and Szterk, 2015; Duan et al., 2015). Besides this, many studies have also indicated wide variation in the content of these nutrients in bovine meat, and the limits of these variations have not been fully defined (Greenfield and Southgate, 2003; Tomović et al., 2011).

The non-significant difference in mineral contents between breeds in this study was similar to the report of Duan et al. (2015) who found no significant breed effect in mineral content of cattle. However, this result was in contrast with the findings of Domaradzki et al. (2016) who reported a significant breed effect on mineral concentration of beef from Polish native cattle. The impact of thermal processing on the mineral content of beef and liver in this study was relatively minimal compared to the findings of Czerwonka and Szterk (2015) who reported great loss of elemental nutrients after cooking different meat cut through roasting, grilling and frying. This shows that sous-vide cooking methods can preserve the elemental constituents of beef and liver during the cooking process compared to other conventional methods.

\section{Conclusion}

The findings of this study revealed that breed did not have significant effect on fatty acid and mineral composition of raw beef and liver. It also showed that the liver had higher percentage of intramuscular fat, fat free dry matter, PUFA, $n-6$ and $n-3$ than the musculus longissimus dorsi. It was also observed that the concentration of minerals in liver was similar to beef. Although, there was no pronounced effect of sous-vide cooking temperature on fatty acid and mineral composition of beef and liver compared to uncooked samples. Moreover, the concentration of PUFA, $n-6$, and $n-3$ was lower in beef than liver after cooking. This study has demonstrated that sous-vide cooking method can preserve the nutritional properties of meat products.

\section{Ethics statement}

This study protocol was reviewed and approved by the institutional review board of the university of Fort Hare, Routh Africa (MUC071 SFAL01). 


\section{Acknowledgements}

The authors are grateful to Govan Mbeki Research and Development Centre (GMRDC) of the University of Fort Hare (UFH) for providing financial assistance for this work as part of the UFH's support to the Department of Science and Technology/National Research Foundation (DST/NRF) South African Research Chairs Initiative (SARChI) Chair in Meat Science: Genomics to Nutriomics which is jointly hosted by the Universities of Stellenbosch and Fort Hare.

\section{References}

A 1 fa i a C.M.M., Castro M.L.F., Martins S.I.V., Portugal A.P.V., Alves S.P.A., Fonte s C.M.G.A., B e s s a R.J.B., Prate s J.A.M. (2007). Effect of slaughter season on fatty acid composition, conjugated linoleic acid isomers and nutritional value of intramuscular fat in BarrosãPDO veal. Meat Sci., 75: 44-52.

Alfai a C.M.M., Alves S.P., Lopes A.F., Fernandes M.J.E., Costa A.S.H., Fonte s C.M.G.A., C a s $t$ r o M.L.F., B e s s a R.J.B., P r a t e s J.A.M. (2010). Effect of cooking methods on fatty acids, conjugated isomers of linoleic acid and nutritional quality of beef intramuscular fat. Meat Sci., 84: 769-777.

Araya J., Rodrigo R., Pettinelli P., Araya A.V., Poniachik J., Videla L.A. (2010). Decreased liver fatty acid $\Delta-6$ and $\Delta-5$ desaturase activity in obese patients. Obesity, $18: 1460-1463$.

Badiani A., Montellato L., Bochicchio D., Anfossi P., Zanardi E., Maranesi M. (2004). Selected nutrient contents, fatty acid composition, including conjugated linoleic acid, and retention values in separable lean from lamb rib loins as affected by external fat and cooking method. J. Agric. Food Chem., 52: 5187-5194.

B a $1 \mathrm{~d}$ w in D.E. (2012). Sous vide cooking: A review. Int. J. Gastron Food Sci., 1: 15-30.

Bonsmara SA (2016). Bonsmara breed. http://bonsmara.co.za/eng/

Chilliard Y., Ferlay A., R ou el J., L a mberet G. (2003). A review of nutritional and physiological factors affecting goat milk lipid synthesis and lypolysis. J. Dairy Sci., 86: 1751-1770.

Czerwonka M., Szterk A. (2015). The effect of meat cuts and thermal processing on selected mineral concentration in beef from Holstein-Friesian bulls. Meat Sci., 105: 75-80.

Czerwonka M., Szterk A., Waszkiewicz-Robak B. (2014). Vitamin $B_{12}$ content in raw and cooked beef. Meat Sci., 96: 1371-1375.

De S m e t S. (2012). Meat, poultry, and fish composition: Strategies for optimizing human intake of essential nutrients. Anim. Frontiers, 2: 10-16.

Domaradzki P., F lorek M., Staszowska A., Litwińczuk Z. (2016). Evaluation of the mineral concentration in beef from Polish native cattle. Biol. Trace Elem. Res., 171: 328-332.

Du an Q., Tait Jr. R.G., S chne id e r M.J., B e it z D.C., Wh e eler T.L., Sh a c k el ford S.D., C und iff L.V., R e e c y J.M. (2015). Sire breeds effect on beef longissimus mineral concentrations and their relationships with carcass and palatability traits. Meat Sci., 106: 25-30.

Enser M., Hall e t t K.G., H ew e t t B., F urs e y G.A.J., Wood J.D., H arring ton G. (1998). The Polyunsaturated fatty acid composition of beef and lamb liver. Meat Sci., 49: 321-327.

F lorek M., Litwińczuk Z., Skałecki P., Kędzierska-Matysek M., Grodzicki T. (2012). Chemical composition and inherent properties of offal from calves maintained under two production systems. Meat Sci., 90: 402-409.

Folch J., Le e s M., S lo an e-St an ley G.H. (1957). A simple method for the isolation and purification of total lipids from animal tissue. J. Biol. Chem., 226: 497-509.

Garc1a-Segovia P., Andres-Bello A., Martınez-Monzo J. (2007). Effect of cooking method on mechanical properties, color and structure of beef muscle (M. pectoralis). J. Food Eng., 80: 813-821.

G e r b e r N., S c h e e d e r M.R.L., We n k C. (2009). The influence of cooking and fat trimming on the actual nutrient intake from meat. Meat Sci., 81:148-154. 
Gorsuch T.T. (1970). The destruction of organic matter (1st edition). Oxford, New York, Toronto, Sydney, Braunschweig: Pergamon Press Ltd, 160 pp.

Green fi eld H., S o u th gat e D.A.T. (2003). Food composition data: Production, management and use. www.fao.org/fileadmin/templates/food composition. Accessed on 11/09/2015.

J a y a thilakan K., Sult an a K., R a dhakrishna K., B aw a A.S. (2012). Utilization of byproducts and waste materials from meat, poultry and fish processing industries: a review. J. Food Sci. Technol., 49: 278-293.

K urt S., Z orba Ö. (2007). Emulsion characteristics of beef and sheep offal. J. Muscle Foods., 18: $129-142$

L e ga ko J.F., D inh T.T.N., Mille r M.F., B rooks J.C. (2015). Effects of USDA beef quality grade and cooking on fatty acid composition of neutral and polar lipid fractions. Meat Sci., 100: 246-255.

L i R., Yu Q., H a n L., C a o H. (2014). Nutritional characteristics and active components in liver from Wagyu $\times$ Qinchuan cattle. Korean J. Food Sci. Anim. Resour., 34: 214-220.

L o p e s A.F., A 1 fa i a C.M.M., P a rt i dá ri o A. M.C.P.C., L e m o s J.P.C., P ra te s J.A.M. (2015). Influence of household cooking methods on amino acids and minerals of Barrosã-PDO veal. Meat Sci., 99: 38-43.

Mourouti N., Kontogianni M.D., Papavagelis C., Plytzanopoulou P., Vas silakou T., Psaltopoulou T., Malamos N., Linos A., Panagiotakos D.B. (2015). Meat consumption and breast cancer: A case-control study in women. Meat Sci., 100: 195-201.

Nantapo C.W., Muchenje V., Nkukwana T.T., Hugo A., Descalzo A., Grigioni G., H o ffm a n L.C. (2015). Socio-economic dynamics and innovative technologies affecting healthrelated lipid content in diets: Implications on global food and nutrition security. Food Res. Int., 76 : 896-905.

Orellan a C., P eña F., García A., P erea J., Martos J., Domenech V., A cero R. (2009). Carcass characteristics, fatty acid composition, and meat quality of Criollo Argentino and Braford steers raised on forage in a semi-tropical region of Argentina. Meat Sci., 81: 57-64.

$\mathrm{O}$ z F., Z i k i r o v E. (2015). The effects of sous-vide cooking method on the formation of heterocyclic aromatic amines in beef chops. LWT - Food Sci. Technol., 4: 120-125.

Reykdal O., Rabieh S., Steingrims dottir L., Gunnlaugs dottir H. (2014). Minerals and trace elements in Icelandic dairy products and meat. J. Food Compost. Anal., 24: 980-986.

Roldan M., Antequera T., Armenteros M., Rui z J. (2014). Effect of different temperaturetime combinations on lipid and protein oxidation of sous-vide cooked lamb loins. Food Chem., 149: $129-136$.

Sanchez del Pulgar J., Gazquez A., Ruiz-Carrascal J. (2012). Physico-chemical, textural and structural characteristics of sous-vide cooked pork cheeks as affected by vacuum, cooking temperature, and cooking time. Meat Sci., 90: 828-835.

S arriés M.V., Murray B.E., Moloney A.P., Troy D., B eria in M.J. (2009). The effect of cooking on the fatty acid composition of longissimus muscle from beef heifers fed rations designed to increase the concentration of conjugated linoleic acid in tissue. Meat Sci., 81: 307-312.

S everi S., B ed og ni G., M an zi e ri A.M., P oli M., B a t t is t in i N. (1997). Effects of cooking and storage methods on the micronutrient content of foods. Eur. J. Cancer Prev., 6: 521-524.

To movi ć V.M., P e trović L.S., To m o vić M.S., K e v reša n Ž.K., D ž i n i c N.R. (2011). Determination of mineral contents of semimembranosus muscle and liver from pure and crossbred pigs in Vojvodina (northern Serbia). Food Chem., 124: 342-348.

Valenzuela R., Es pinosa A., González-Mañán D., D 'Espessailles A., Fernánd e z V., Vi d e l a L.A., Ta p i a G. (2012). n-3 long-chain polyunsaturated fatty acid supplementation significantly reduces liver oxidative stress in high fat induced steatosis. PLoS One, 7 (10): 46400 .

Va u d a g n a S.R., S á n c h e z G., N e i r a M.S., In s a n i E.M., P i c a 11 o A.B., G a 11 in g e r M.M., Lasta J.A. (2002). Sous vide cooked beef muscles: effects of low temperature-long time (LT-LT) treatments on their quality characteristics and storage stability. Int. J. Food Sci. Technol., 37: $425-441$.

Xie X., Meng Q., Cui Z., Ren L. (2012). Effect of cattle breed on meat quality, muscle fiber characteristics, lipid oxidation and fatty acids in China. Asian-Austral. J. Anim. Sci., 25: 824-831. 
Zhang Y., Wang X., Wang W., Z han J. (2014). Effect of boiling and frying on nutritional value and in vitro digestibility of rabbit meat. Afr. J. Food Sci., 8: 92-103.

Received: 29 III 2016

Accepted: 30 XI 2016 